\title{
Rapid and effective processing of blood specimens for diagnostic PCR using filter paper and Chelex-100
}

\author{
J M Polski, S Kimzey, R W Percival, L E Grosso
}

\begin{abstract}
Aim-To provide a more efficient method for isolating DNA from peripheral blood for use in diagnostic DNA mutation analysis.

Methods-The use of blood impregnated filter paper and Chelex-100 in DNA isolation was evaluated and compared with standard DNA isolation techniques.

Results-In polymerase chain reaction (PCR) based assays of five point mutations, identical results were obtained with DNA isolated routinely from peripheral blood and isolated using the filter paper and Chelex-100 method.

Conclusion-In the clinical setting, this method provides a useful alternative to conventional DNA isolation. It is easily implemented and inexpensive, and provides sufficient, stable DNA for multiple assays. The potential for specimen contamination is reduced because most of the steps are performed in a single microcentrifuge tube. In addition, this method provides for easy storage and transport of samples from the point of acquisition. (F Clin Pathol: Mol Pathol 1998;51:215-217)
\end{abstract}

Keywords: DNA isolation; polymerase chain reaction; hereditary disorders

Isolation of DNA from peripheral blood is the initial step in many clinical polymerase chain reaction (PCR) based DNA tests. Traditional isolation procedures provide abundant quantities of highly purified DNA that generally exceed (both in quantity and quality) that required for successful PCR; however, they are relatively expensive, slow, and labour intensive, and they include multiple transfers and exposure to toxic chemicals. To overcome these problems, alternative extraction methods incorporating improvements and simplifications of specimen processing have been reported. ${ }^{1-5}$ Commercial products that eliminate the use of toxic substances and decrease the time of processing are also available (for example, QIAamp blood kit, Qiagen Inc, Chatsworth, California, USA). In our experience, however, the use of such products does not eliminate the need for preparation of a buffy coat.

Chelex-100, a chelating resin, has been used successfully to recover DNA from the following: forensic specimens, ${ }^{6}$ formalin fixed, paraffin wax embedded tissue, ${ }^{7}$ whole blood of mice, ${ }^{8}$ dried blood spots on filter paper discs (for virology testing), ${ }^{9}$ and cultures or clinical samples (for microbiology testing). ${ }^{10}$ The aim of our study was to determine whether Chelex100 could be used with whole blood impregnated filter paper discs (rapid processing) as a cost effective method of DNA recovery for routine PCR based DNA clinical diagnostic testing for inherited disorders.

\section{Materials and methods}

SAMPLES

Fifteen consecutive peripheral blood samples (5 ml) submitted to the DNA diagnostic laboratory were used; $100 \mu$ l was removed and used for rapid processing. The remainder of the peripheral blood was used to prepare a buffy coat and for routine DNA isolation using the Qiagen QIAamp blood kit (control DNA) in accordance with the manufacturer's instructions. ${ }^{11}$ Briefly, $200 \mu \mathrm{l}$ of buffy coat was incubated with proteinase $\mathrm{K}$, mixed with ethanol, and centrifuged with a QIAamp spin column. After the spin column was washed, DNA was eluted with preheated buffer.

\section{RAPID GENOMIC DNA EXTRACTION}

Filter paper discs $(7 \mathrm{~mm}$ ) (Whatman 3M; Midwest Scientific, Valley Park, Missouri, USA) were punched directly into $500 \mu \mathrm{l}$ sterile microcentrifuge tubes using a sterile paper punch. Peripheral blood $(10 \mu \mathrm{l})$ was spotted on to the paper filter disc in a microcentrifuge tube. After air drying for 30 minutes at room temperature, $500 \mu \mathrm{l}$ of sterile millipore water was added to the tube and the sample was vortexed at room temperature for 10 minutes. After complete removal of the supernatant (necessary for reliable amplification), $200 \mu \mathrm{l}$ of 5\% Chelex-100 (Bio Rad Laboratories, Hercules, California, USA) was added; the tubes were incubated in a thermal cycler (Barnstead Thermolyne, Dubuque, Iowa, USA) for 90 minutes at $56^{\circ} \mathrm{C}$ followed by a 10 minute incubation at $99^{\circ} \mathrm{C}$. After cooling, the samples were vortexed briefly and centrifuged. The supernatant was used as a substrate in PCR reactions.

\section{AMPLIFICATION}

Mutations analysed were G1691A (factor V Leiden - the mutation of factor $\mathrm{V}$ associated with activated protein $\mathrm{C}$ resistance), C667T (the mutation of methylenetetrahydrofolate reductase (MTHFR) associated with hyperhomocysteinaemia and a thermolabile phenotype), C282Y and H63D (mutations identified in patients with haemochromatosis; the gene has been referred to as HLA-H and HFE), and $\mathrm{Pl}^{\mathrm{A} 1} / \mathrm{Pl}^{\mathrm{A} 2}$ of GPIIIa (a polymorphism of a component of the platelet integrin receptor GPIIIa/IIb). ${ }^{12-15}$ Both the DNA extracted by
Accepted for publication 7 April 1998 


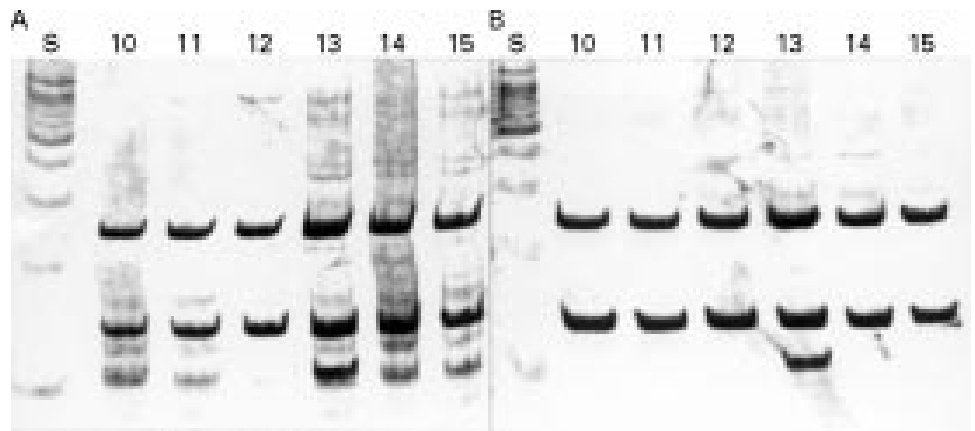

Figure 1 Analysis of HFE mutations (C282Y). Silver stained 5\% polyacrylamide gels containing Rsa1 restriction digestion of primary PCR products from five matched patient samples. (A) rapid processing method and (B) control processing method. Identical results were obtained with both methods of DNA isolation.

rapid processing and control DNA were subjected to PCR in thermal cyclers (G1691A in a Hybaid Omnigene, Hybaid Limited, Middlesex, UK; remaining reactions in a Barnstead Thermolyne). The amplification solutions and conditions of amplification of control DNA for G1691A, C677T, C282Y , H63D, and GPIIIa were derived from data published previously. ${ }^{12-15}$ The conditions of the PCR reactions were changed for the rapid processing to compensate for an anticipated lower quantity of DNA. These modifications included an increase in the number of cycles to 45 (from 35) for HFE, G1691A, and GPIIIa. The substrate DNA volume was changed from 1 to $2 \mu \mathrm{l}$ for MTHFR and from 12.5 to $2 \mu \mathrm{l}$ for G1691A. All PCR products were analysed on $4 \%$ NuSieve agarose (FMC BioProducts, Rockland, Maine, USA) gels to confirm synthesis of the appropriate genomic fragments. The PCR products were digested overnight at $37^{\circ} \mathrm{C}$ using the manufacturer's recommended conditions with the restriction enzymes Hinf1, Rsa 1, Bcl1, Ncil (Promega, Madison, Wisconsin, USA), and Mnl1 (New England Biolabs, Beverly, Massachusetts, USA) for C677T, C282Y,H63D, GPIIIa, and G1691A, respectively. Restriction fragments were visualised following electrophoresis in either a 5\% polyacrylamide gel (followed by silver staining for C282Y, H63D, and GPIIIa) or a $4 \%$ NuSieve agarose gel (FMC Bioproducts, Rockland, Maine, USA), with ethidium bromide (Sigma Chemical Co, St Louis, Missouri, USA) staining. All assays included both wild-type and mutant controls. The genotypes were identified without knowledge of the identity of the specimen or the results of other analyses. PCR amplification of DNA samples stored at $4^{\circ} \mathrm{C}$ was performed up to three months after isolation from filter paper.

RESOURCE ALLOCATION

Total time, committed technician time, reagents, and disposable items used in specimen

Table 1 Comparison between the two methods of DNA isolation for specimens processed either individually or in a batch of 12

\begin{tabular}{lllll}
\hline Resources/sample & $\begin{array}{l}\text { Control: } \text { single } \\
\text { sample }\end{array}$ & $\begin{array}{l}\text { Rapid: single } \\
\text { sample }\end{array}$ & $\begin{array}{l}\text { Control: } 12 \\
\text { samples }\end{array}$ & $\begin{array}{l}\text { Rapid: } 12 \\
\text { samples }\end{array}$ \\
\hline Cost of disposables (US\$) & 3.57 & 0.15 & 3.57 & 0.15 \\
Committed time (minutes) & 30 & 3 & $7.5^{\star}$ & $1^{\star}$
\end{tabular}

${ }^{\star}$ Committed total personnel time divided by the number of specimens, that is, the time allocated to a single specimen in a batch. processing, either processed individually or batch processed (12 samples), for both routine DNA isolation and rapid processing were recorded.

\section{Results}

Control paper filter discs without blood yielded no signal after any PCR (data not shown). After PCR, agarose gel electrophoresis demonstrated comparable amounts of the appropriate DNA fragment both with the rapid Chelex-100 processing samples and control DNA samples. Amplification was successful in all cases on the first attempt. PCRs of rapidly processed peripheral blood samples in which the Chelex100 solution was replaced with water, PCR buffer, or Tris/EDTA buffer were unsuccessful (data not shown).

After restriction digestion and electrophoretic separation, identical genotypes were obtained with QiAmp isolated and rapid processed DNA for all sequences examined. In some cases, slight differences were noted between rapid processing and control results, although these did not interfere with the interpretation of the results. For example, in the analysis of C282Y, the silver stained polyacrylamide gel produced after Rsa 1 restriction enzyme digestion of the rapid processed DNA had more background staining when compared with the control (fig 1). This slight increase in noise did not interfere with interpretation of the results. The C677T (MTHFR) and G1691A (factor V Leiden) rapid processing agarose gels showed fainter bands than control gels; however, in all cases the results were clearly interpretable.

When comparing the costs of both DNA isolation methods including supplies and time devoted, it was evident that the rapid processing method required substantially fewer resources (table 1). Evaluation of subsequent steps in specimen analysis demonstrated little difference in time or cost.

\section{Discussion and summary}

Chelex-100 is a chelating resin with a high affinity for multivalent metal ions. By binding to and removing ions during the isolation of DNA, damage to DNA (when heated) is prevented and inhibitors of Taq DNA polymerase are reduced. Together, these two factors allow the successful use of minimally processed whole blood samples in PCR. ${ }^{5}$ DNA extraction procedures using Chelex-100 resin are very versatile, do not require buffy coat preparation, and can use dried blood as a source of DNA.

Our study compared a rapid processing method with a control DNA isolation method. Minor modifications of the PCR conditions were made to deal with low concentrations of the recovered DNA and/or the presence of inhibitors. These minor modifications included an increase in the number of cycles in the PCR programme and a change in the volume of substrate DNA used in each PCR 
reaction. In addition, polyacrylamide gel electrophoresis coupled with silver staining provided excellent visualisation of bands and ease of interpretation in a case of faint bands. In all cases, the genotypes identified were identical.

Our results indicate that recovery of DNA from filter paper impregnated with whole blood is a useful method of preparing DNA for PCR based genetic testing. This method is cost effective, non-toxic, easily applied, and most of the steps can be performed in a thermal cycler. In addition, the entire procedure is performed in a single container, reducing the chances of sample contamination, loss of the sample, or mislabelling. For tests performed at a later date or different site, the use of paper filter as a sample collection and transport medium provides for easy collection of a small amount of blood, and ease of transport and storage after spotting and drying of the blood sample. DNA in filter paper impregnated with whole blood remains relatively stable at room temperature for at least 4.5 months. ${ }^{16}$

The rapid processing appears especially well suited for field research or population screening and has the potential for improving specimen processing in a clinical DNA laboratory. While methods incorporating whole blood impregnated filter paper in the PCR reaction might be easier to implement for a single test, after a single processing step this method provides sufficient stable DNA for multiple assays either performed immediately or at a later date.
1 Mercier B, Gaucher C, Feugeas O, et al. Direct PCR from whole blood, without DNA extraction. Nucleic Acids Res 1990;18:5908.

2 Grimberg J, Nawoschik S, Belluscio L, et al. A simple and efficient non-organic procedure for the isolation of genomic DNA from blood. Nucleic Acids Res 1989;17: 8390 .

3 Laitinen J, Samarut J, Holtta E. A nontoxic and versatile protein salting-out method for isolation of DNA. BioTechniques 1994;17:316-22.

4 Kendall TL, Byerley DJ, Dean R. Isolation of DNA from blood. Anal Biochem 1991;195:74-6.

5 Singer-Sam J, Tanguay RL, Riggs AD. Use of Chelex to Singer-Sam J, Tanguay RL, Riggs AD. Use of Chelex to
improve the PCR signal from a small number of cells. improve the PCR signal

6 Walsh PS, Metzger DA, Higuchi R. Chelex 100 as a medium for simple extraction of DNA for PCR-based typing from forensic material. BioTechniques 1991;10:506-13.

7 Sepp R, Szabo I, Uda H, et al. Rapid techniques for DNA extraction from routinely processed archival tissue for use in PCR. F Clin Pathol 1994;47:318-23.

8 Wingberg G. A rapid method for preparing DNA from blood, suited for PCR screening of transgenes in mice. PCR Methods Appl 1991;1:72-4.

9 Kain KC, Lanar DE. Determination of genetic variation within Plasmodium falciparum by using enzymatically within Plasmodium falciparum by using enzymatically amplified DNA from filter paper disks impre
whole blood. $\mathcal{F}$ Clin Microbiol 1991;29:1171-4.

10 de Lamballerie X, Zandotti C, Vignoli C, et al. A one step microbial DNA extraction method using "Chelex 100" suitable for gene amplification. Res Microbiol 1992;143: 785-90.

11 QIAamp blood kit and QIAamp tissue kit handbook. Chatsworth California: Qiagen Inc, 1996

12 Bertina RM, Koeleman BPC, Koster T, et al. Mutation in blood coagulation factor $\mathrm{V}$ associated with resistance to activated protein C. Nature 1994;369:64-7.

13 Frosst $\mathrm{P}$, Blom HJ, Milos R, et al. A candidate genetic risk factor for vascular disease: a common mutation in methylenetetrahydrofolate reductase. Nat Genet 1995;10:111-13.

14 Jin Y, Dietz HC, Nurden A, et al. Single-strand conformation polymorphism analysis is a rapid and effective method in the identification of mutations and polymorphisms in the gene for glycoprotein IIIa. Blood 1993;82:2281-8

15 Feder JN, Gnirke A, Thomas W, et al. A novel MHC class I-like gene is mutated in patients with hereditary haemochromatosis. Nat Genet 1996;13:399-408.

16 McCabe ERB, Huang S, Seltzer WK, et al. DNA microextraction from dried blood spots on filter paper blotters: potential applications to newborn screening. Hum Genet 1987;75:213-16. 